\title{
Teacher job performance: The mediating role of work culture
}

\author{
Sitti Nurbaya \\ Doctoral Student in Faculty of Economics, \\ University of Muslim Indonesia, Makassar \\ Mansyur Ramly \\ Professor in Management, Postgraduate School, \\ University of Muslim Indonesia, Makassar \\ Bahar Sinring \\ Professor in Management, Postgraduate School, \\ University of Muslim Indonesia, Makassar \\ Baharuddin Latif \\ Associate Professor, Postgraduate School, \\ University of Muslim Indonesia, Makassar
}

\begin{abstract}
The purpose of this study is to explain the effect of competence, motivation and work discipline on culture; to know and explain the effect of competence, motivation and work discipline on honorary teacher performance; to know and explain the effect of work culture on honorary teacher; and knowing to explaining the effect of competence, motivation and work discipline as a mediates work culture on honorary teacher performance on elementary school teachers in Makassar City. The study was conducted in elementary schools with a population of elementary school honorary teachers who had a Limited duration contract in 8 sub-districts in Makassar City totaling 1,495 people. A sample of 317 respondents used the Slovin formula. The data from the questionnaire were analyzed using the Structural Equation Model using AMOS 18. The results of the study found that the work competence, motivation and discipline directly had a positive and significant effect on teachers work culture. Work competence, motivation discipline directly has a positive and significant effect on honorary teacher performance. Teachers work culture directly has a positive and significant effect on honorary teacher performance. The three exogenous variables (competence, work discipline and work motivation) have a significant positive effect on honorary teacher performance as a mediating role of teacher's work culture.
\end{abstract}

Keywords: Work competence, motivation, discipline, work culture, honorary teacher job performance.

\section{INTRODUCTION}

Education greatly determines the progress and quality of a nation. Advanced nations have good education. Good education is obtained from good quality teachers. The teacher is a key factor in the quality of education and the progress of a nation. The teacher has the duty to serve the community in the field of education. In this profession a teacher must provide optimal and best service in the field of education to the public. In particular, a teacher is required to provide professional services to a student so that a learning goal is easily achieved. A teacher who is said to be a professional is a teacher who has skills and expertise that are specialized in the field of teacher training. 
The teacher is a professional educator who has the main task of educating, teaching, guiding, directing, training, evaluating, and evaluating students in early childhood education, basic education, and secondary education. A teacher has a position as a professional at the level of early childhood education, basic education, and secondary education, in the formal education pathway appointed in accordance with the laws and regulations (Article 2, Republic of Indonesia Law Number 14 of 2005 concerning Teachers and Lecturers). Factors that influence the success of education include teachers, students, facilities and infrastructure, educational environment, curriculum. Of these factors, the teacher in the learning process activities in school occupies a very important position and without ignoring other supporting factors, the teacher as the subject of education greatly determines the success of education itself. It must be recognized that teachers are a major factor in the education process. Even though the educational facilities are complete and sophisticated, but if it is not supported by the existence of a qualified teacher, it is impossible to create a maximum learning and learning process.

Teachers as implementers of national education are key factors in the success of education in Indonesia. The teacher is required to give birth to a generation that is qualified and has competitiveness in all fields of science. However, the reality is not as expected, the teacher's performance still needs to be improved. Teacher performance has not been maximized because the school has not implemented a work culture in the school environment.

The school is a formal organization and is a container for the Indonesian empowerment of the 1945 constitution, namely Chapter XIII concerning education Article 31 paragraph (1) Every citizen has the right to receive teaching, paragraph (2) The Government undertakes and organizes a national teaching system regulated by law invited. In each school, it will certainly be colored by each organization's culture, although the main basis for its implementation is based on existing government regulations. School organizational culture is a guideline for the behavior of all people involved in the learning process of students.

Kinicki \& Kreitner (2009: 36) Organizational Culture is "the set of shared, taken-for-granted implicit assumptions that group holds and determines how it perceives, thinks about, and reacts to its various environments. Based on the description, it means that organizational culture is the assumptions that are accepted in the organization group about the reaction of all its members to the organizational environment of the individuals in it. Similarly, the organizational culture is inseparable from the work culture, but each school must have a different work culture in accordance with the beliefs held by the people involved in it, agreed to be run together. The phenomenon that occurs in the world of education in Makassar City, especially in elementary schools, most teachers who teach are still honorary. The number of honorary teachers who have a Limited Time Contract Decree is 2,328 people with details 270 for junior high school honorarium teachers, 1,909 people for elementary school teachers, 4 for kindergarten teachers, and 145 for education staff, and about 327 for have not received a Limited Time Contract Decree because the educational qualifications are not linear and the working period is not enough 2 (two) years (Makassar Education Agency, 2017).

The honorary teachers themselves are appointed by the principal or chairman of the foundation based on emotional closeness, recommendations, and kinship relations. The teacher's qualifications and competencies are not the only factor for one's acceptance of being an honorary teacher in elementary school but only as a supplement. The qualifications and competencies possessed by honorary teachers are not comparable to the learning process in elementary school. Teachers are required to master all subjects in primary schools including subjects in Religious Education, Citizenship Education, Indonesian Language, Mathematics, 
Natural Sciences, Social Sciences, Cultural Arts Skills, Physical Education and health, and local content such as English, Regional Languages, and Information and Communication Technology.

This lack of honorary teacher competence has an impact on the performance of Makassar City honorary teachers. Teacher Competency Test Results (UKG) in the last year (2015) showed low teacher competency. Indonesia's low ranking in several world rankings on students' abilities in the fields of reading, mathematics, and science also indirectly shows the weaknesses of teacher competencies. The national average of the 2015 pedagogical and professional Teacher Competency Test (UKG) in the field is $53.02 \%$. For pedagogical field competencies only, the national average is only $48.94 \%$, which is below the minimum competency standard (Minimum Competency Standard), which is 55.00\% (Maulipaksi, 2016).

There were around 12,683 teachers in Makassar following this competency. They consisted of Kindergarten (TK) levels 1,426 elementary school teachers (SD) 5,183 teachers of junior high school (SMP) 2,643 teachers, high school (SMA) 1,724 teachers, vocational high school (SMK) 1,226 teachers, 171 supervisors, and special school teachers (SLB) 310. The standard score of the Teacher Competency Test (UKG) is $55.00 \%$. Meanwhile, the teacher competency test (UKG) obtained in Makassar was 30, 40 and 50 (Makassar City Education Office, 2015).

The low Teacher Competency Test (UKG) results show that honorary teacher competencies need to be improved and need to be added with one competency, namely renaissance competence. Renaissance competency is teacher competence that must be spurred with time to improve abilities and self-actualization to the level of enlightenment, thought, and ideas understood by the people, and capable of arousing enthusiasm for learning and changing people's lives. To become a renaissance teacher (teacher who has the ability to give enlightenment) must learn super hard throughout life.

The discipline of knowledge is not just one, but all scientific disciplines are studied and studied so that they master all existing disciplines, are able to associate, connect, and combine various dimensions of existing knowledge. Renaissance teachers are teachers who have the ability to combine two idealism, namely idealism of thought and social idealism. Idealism of thought comes from the field of knowledge, discourse, and theory. Whereas social idealism comes from foresight and carefulness in coming into contact with the reality of tyrannical human problems, distortion, exploitation, far from justice, prosperity, and progress.

Renaissance teachers are teachers who dare to fight and sacrifice for others. Dare to struggle and sacrifice in order to realize big dreams driving the world's changes is the starting point of starting a big thing. Renaissance teachers are the teachers who always sow the seeds of the future, potential young people who will fill the future civilization. And being a renaissance teacher, the results are not important because what determines is the process that is carried out in a disciplined, consistent, systematic and unhurried manner.

The renaissance teacher does not feel at the peak of his career or on the throne of social science, but prefers to position himself as a public servant who devotes his time, energy, wealth and thoughts to the advancement of education. With the phenomenon that occurs in the world of education, especially in the city of Makassar, researchers argue that the Law No. 14 of 2015 concerning Teachers and Lecturers includes 4 (four) competencies (pedagogical, social, personality, and professional) still need to add one competency namely renaissance competence (ability to enlighten). 
Teachers who have a Limited Time Contract SK get a salary of IDR 850,000 per month which is still far below the Regional Minimum Wage standard so there are still honorary teachers who are looking for additional income by selling (food and drink) at school, becoming drivers of grab motorbikes, open private lessons to fulfill their daily needs. Not to mention the honorarium teachers who are still contracting or boarding houses must of course cover their rented costs. The phenomenon that occurs in the world of education in Makassar City, there is omission in the classroom related to the learning process because the teacher feels insecure in educating.

The number of teachers reported by parents of students to the police is only because they want to discipline their students. The teacher is not appreciated for efforts made to shape the character of his students. This is because there is no communication that is well established between the teacher and parents of students so that parents only hear information from their children without clarifying issues to the teacher and the school. With the phenomenon that occurs in elementary schools in the city of Makassar, the theory that the researchers use is the theory of Maslow's Hierarchy of Needs, where physiological needs still rank first, security needs rank second, social needs in third place, fourth order awards and self-actualization in fifth place in terms of motivation of Elementary School honorary teachers in Makassar City.

Another phenomenon that occurs in elementary schools is the lack of discipline of teachers in teaching. They come to school only to abort their obligations. Teaching classroom is the second priority. The first priority is family. It's too late to come to school for the reason of taking children to school first, taking care of sick children, taking parents to treatment, traffic jams, attending family marriages and so on so that the learning process does not work as applied. Work culture that cannot be applied because it is still constrained by the phenomena. Unoptimal competency, low motivation and low work discipline have caused the performance of honorary teachers to not be maximal.

The teacher is incompetent because he cannot use a computer, the teaching method is lectured, cannot apply active and enjoyable teaching methods, cannot use and process information from the internet, and is not contextual. For example in science Olympiad competitions, Makassar City has a represented South Sulawesi Province in the event. Especially for honorary teachers in primary schools in addition to the four competencies (pedagogical, social, personality and professional competencies) that must be possessed, one competency needs to be added, namely the renaissance competence.

Renaissance competence is the competency that must be possessed by the teacher as a climax competency that must be completed by the teacher. Renaissance competence is an enlightenment competency because it not only looks at the breadth and depth of its knowledge, but also the enlightenment effects caused by its thinking. Enlightenment that brings awareness, repentance, a strong will to change, and active movements towards a committed and progressive future.

The teacher must be able to carry out this great task in order to reconstruct a dynamic and productive future. Teachers are educators and educators who are intentionally influencing others to achieve educational goals (Asmani; 2009: 207). In the industrial era 4.0 where teachers are required to master at least one foreign language, master science and technology, and have the spirit of entrepreneurship. This is written in Holy Quran.

"For each one is successive [angels] before and behind him who protect him by the decree of Allah. Indeed, Allah will not change the condition of a people until they 
change what is in themselves. And when Allah intends for a people ill, there is no repelling it. And there is not for them besides Him any patron (Ar-Rad Ayat 13.11)"

Based on the data and phenomena mentioned above, efforts need to be made by the Makassar City Government to improve teacher performance. Improving the teachers' performance can be improving from basic education to secondary education both of public and private. Improving the performance of teachers must be synergistic with the implementation of a work culture that affects competency, motivation and high work discipline. It was found that there is a gap theory proposed by Dessler (2008: 322) that the success of human resources in improving performance is determined by the existence of aspects of competence, motivation and work discipline that support the achievement of the goals of human resource management organizations.

Hasbullah (2006) supports this theory in the prospective world of education that the success of educators in developing a national education system is inseparable from the importance of competence, motivation and work discipline that support influencing teacher performance. This means that teacher competence is expected to be improved through pedagogical, personal, social, professional, and renaissance competencies in influencing its performance. Motivation is expected to continue to be improved in the form of fulfilling physiological needs, security, social interaction, appreciation and self-actualization to improve its performance.

Work discipline in form of behavior, learning, obedience, obedience, and loyalty that influence teacher performance. Gap theory that shows that competence, motivation, and work discipline that affect teacher performance as stated in the lost theory by Gagne (2002) that the quality of education will be lost if performance is not improved. This is written in Holy Quran.

"And say, "Do [as you will], for Allah will see your deeds, and [so, will] His Messenger and the believers. And you will be returned to the Knower of the unseen and the witnessed, and He will inform you of what you used to do (At Taubah .105)"

Brain theory (Helen, 2007) stating that the brain of human resources lies in the performance produced. Building the brain of human resources begins with improving competence, motivation and supported by work discipline. The phenomenon of research gap shows that teacher competencies in the form of pedagogic, personality, social, professional and renaissance competencies are not well implemented, making students in adopting the knowledge taught by teachers difficult to accept, given the competencies possessed by teachers have not produced convenience for students in accepting and carrying out the learning process. In line with this phenomenon, the teachers competence and motivate can be improving in activities. This is written in Holy Quran.

"And do not pursue that of which you have no knowledge. Indeed, the hearing, the sight and the heart - about all those [one] will be questioned (Al Isra .36)"

Teachers as social beings always interact with each other well with the principal as leader, teacher friends as colleagues and students as students, teachers are required to interact socially in order to realize the fulfillment of motivation for social needs, but a manifestation of social needs to interact well often lead to gaps or miscommunication, there tends to be individualism often pointed out by principals and teachers, this is because the rarity of activities helps in carrying out the vision, mission and goals of the school is ignored and often leads to conflicts that are not leads to the attitude of mutual respect. Even though teachers 
really want the motivation of social needs to be improving based on four elements, namely communication, collaboration, help and mutual respect.

Teachers in carrying out its activities always understand and interpret that success and achievement is a form of self-actualization. On this basis the teacher strives to develop his selfactualization based on the work performance approach in accordance with the development of science, skill development orientation, work understanding based on responsible experience, and disciplined ability in leadership both himself and the position attached to the teacher.

Realizing the achievement of organizational goals, human resources must be motivated based on the level of their needs. Motivation is the driving element either from within or from outside of the human resources that must be met in order to show optimal results (Handoko, 2007: 151). The motivation needs in Maslow are divided into five hierarchies of ladder fulfillment needs from the lowest level to the top level, namely psychological needs, security, social, appreciation and self-actualization. The phenomenon of competence, low motivation and poor work discipline, are the three components that influence the work culture and the performance of teachers. It can be seen that due to the low level of the three components, it is difficult for teachers to improve the quality of teaching outcomes, frequent timeliness in completing curriculum and Learning Implementation Plans (RPP) that are late, lack initiative to complete work, lack the ability to complete teaching and learning processes well, and low foster the implementation of the cooperation between teachers and students. As a result of a work culture that is not applied, fair if the teacher's performance also lower.

The phenomenon of this research is basically a unique research phenomenon with distinctiveness different from previous researchers such as Stephen William (2005) with the title The Competence, Motivation and Facilities Affecting Performance and Increasing the Quality of Education in Australia College. Like the differences from this research with the research that will be observed that the research Stephen William saw competence based on knowledge, skills, work experience and attitude.

While this research focuses on competency assessment based on pedagogical, personality, social and professionalism, which refers to Law No. 14 Year 2005 on Certification of Teachers and reinforced with competence renaissance. The motivation variable observed by Stephen William (2005) refers to McGregor's motivation theory, while this study refers to motivation needs according to Maslow. Differences of Stephen William (2005) research with this study of work discipline. Observations made by Stephen William (2005) related to the performance to be achieved in improving the quality of education, while this study relates to the application of a maximum work culture in improving teacher performance. Subsequent research related to this research is the research conducted by Miako Shakanawi (2008) whose focus of research is strengthening performance through improving facilities, motivation, and culture and work ability to improve the quality of human resources. The equation of this study lies in the observation of the job performance, work motivation and culture.

While the difference with this study, researchers did not do research on the ability to work, the facilities and the quality of human resources. The results of the research by Miako Shakanawi (2008) state that a strengthening of performance achieved is inseparable from the contribution of improving facilities, motivation, culture and work capabilities that determine the strengthening of performance to produce an achievement in improving human resources. This means that studies conducted by different researchers for this study is not research on the company but on different educational institutions characteristic of the implementation of a performance. That in order to achieve good performance in obtaining work results in quantity, 
quality, efficiency and effectiveness in educational institutions there is a need for a work culture supported by competence, motivation, work discipline to realize a good teaching and learning process that influences teacher performance.

The urgency of the renewal of this research is the emergence of a study of gap theory and research gaps that gave birth to an interesting phenomenon to study and besides that this research has a variable indicator that is specific to the world of education, not a general indicator. Looking at the description of the phenomena and the results of previous studies, it can be said that the variables in this study have similarities in the previous research but the ones that differentiate are the indicators so that it becomes the reason for the researchers to conduct this research

\section{LITERATURE REVIEW}

There are five observed variables consisting of three exogenous variables and two endogenous variables in this study. The exogenous variable in this study consisted of competence, motivation and work discipline. While the endogenous variables are intermediate variables namely work culture and dependent variable, namely honorary teacher performance.

\section{Competency}

Competency refers to the theory of self-competency theory proposed by Albert (2010:13) that one's personal competence can be known from his pedagogic, professional, personality and social abilities.

Based on theoretical and empirical studies and previous research we will analyze the hypothesis:

$\mathrm{H}_{1 \mathrm{a}}$ : Work competence has a significant positive effect on work culture

$\mathrm{H}_{1 \mathrm{~b}}$ : Work competence has a significant positive effect on honorary teacher's performance

\section{Work motivation}

Maslow's Hierarchy of Needs theory, where physiological needs still rank first, security needs rank second, social needs in third place, fourth place award and self-actualization in fifth place.

Based on theoretical and empirical studies and previous research we will analyze the hypothesis:

$\mathrm{H}_{2 \mathrm{a}}$ : Work motivation has a significant positive effect on work culture

$\mathrm{H}_{2 b}$ : Work motivation has a significant positive effect on honorary teacher's performance

\section{Work discipline}

Work Discipline that refers to the theory of the essence. This theory was put forward by Dannis (2010: 55) that the essence of work discipline is built on four pillars, namely the essence of mission, consistency, adaptation and involvement. These four essences are the values of strong adhesives that bring progress and achievement to organizational goals.

Based on theoretical and empirical studies and previous research we will analyze the hypothesis:

$\mathrm{H}_{3 \mathrm{a}}$ : Work Discipline has a significant positive effect on work culture

$\mathrm{H}_{3 \mathrm{~b}}$ : Work discipline has a significant positive effect on honorary teacher's performance. 


\section{Work Culture}

Work culture is a guideline for the behavior of all people involved in the learning process of elementary school students. Work culture is the set of shared, taken-for-granted implicit assumptions that group holds and determines how it perceives, thinks about, and reacts to its various environments (Kinicki \& Kreitner, 2009: 36).

Based on theoretical and empirical studies and previous research we will analyze the hypothesis:

$\mathrm{H}_{4}$ : Work culture has a significant positive effect on honorary teacher's performance.

\section{Honorary teacher's performance}

Gagne (2002) that the quality of education will be lost if performance is not improved. Helen (2007) put forward the brain theory stating that the brain of human resources lies in the performance produced.

$\mathrm{H}_{5 \mathrm{a}}$ : Work competence through work culture has a significant positive effect on honorary teacher's performance

$\mathrm{H}_{5 b}$ : Work motivation through work culture has a significant positive effect on honorary teacher's performance

$\mathrm{H}_{5 \mathrm{c}}$ : Work discipline through work culture has a significant positive effect on honorary teacher's performance.

\section{METHODS}

This research is designed to answer the problems that have been formulated and the objectives to be achieved and test the hypothesis. The location of the study was carried out in elementary schools in the city of Makassar as the object of research to see the influence of competence, motivation and work discipline on work culture and the performance of honorary teachers. This research is scheduled for 3 (three) months. The type of research used consists of 2 (two), namely quantitative and qualitative research. The data source in this study consisted of primary and secondary data.

Data collection techniques (instruments) used was observation, questionnaires, interviews and documentation. The population in this study were all honorary elementary school teachers in Makassar City which numbered 1,909 people, considering that the area of Makassar City was very broad, limited to 8 (eight) sub-districts with 1.495 honorary teachers. The sample is a collection of sampling units selected from a sampling frame. Research that takes samples from a population and uses a questionnaire as a basic data collection tool using the Slovin formula obtained a sample of 317 honorary teachers. Data analysis techniques used in explaining the phenomena in this study are descriptive statistical analysis techniques and Structural equation modeling using analysis of moment structures (AMOS)

\section{RESULTS}

These results using by the Structural Equation Model (SEM) with confirmatory factor analysis (CFA) the AMOS 20.0 program (Analysis of Moment Structure, Arbukle, 1997). The predictive strength of the observation variables both at the individual level and at the construct level is seen through the critical ratio (CR). If the critical ratio is significant, these dimensions will be said to be useful for predicting constructs or latent variables. The variable of construct this study consisted of competence, motivation, work discipline towards work culture and 
performance of elementary honorary teachers. Using the structural equation model from AMOS there will be model indicators that are fit.

The benchmark used in testing each hypothesis is the value of the critical ratio (CR) on regression weight with a minimum value of 2.0 in absolute terms. The criteria used are to test whether the proposed model is compatible with the data or not. Model fit criteria consist of: (1) degree of freedom must be positive, (2) non-significant Chi-square required $(p \geq 0,05)$ and above conservative accepted $(p=0.10)(3)$ incremental fit above 0.90 namely GFI (goodness of fit), Adjusted GFI (AGFI), Tucker Lewis Index (TLI),

The Minimum Sample Discrepancy Function (CMIN) divided by the degree of freedom(DF) and Comparative Fit Index (CFI), (4) low RMSEA (Root Mean Square Error of Approximation). Confirmatory Factor Analysis is used to examine variables that define a construct that cannot be measured directly. The testing variables of this model are grouped into exogenous variables (exogenous variables) and endogenous variables (endogenous variables). Exogenous variables are variables whose values are determined outside the model. While endogenous variables are variables whose values are determined through equations or from the relationship model formed (Hair et al., 2006),

Included in the group of exogenous variables are measurements of competence, motivation and work discipline, while those classified as endogenous variables are work culture and performance. Analysis of the variable construct model is carried out in six stages. The construction model that has not met the criteria of goodness of fit indices with the chi-squared value is still large and there are some criteria that do not fit the value cut-off specified, so modification of the model is done by correlating the indicator error according to the instructions from modification indices. Next step 6 is the result of AMOS SEM analysis which is the final stage in this analysis in full can be seen in following the figure:

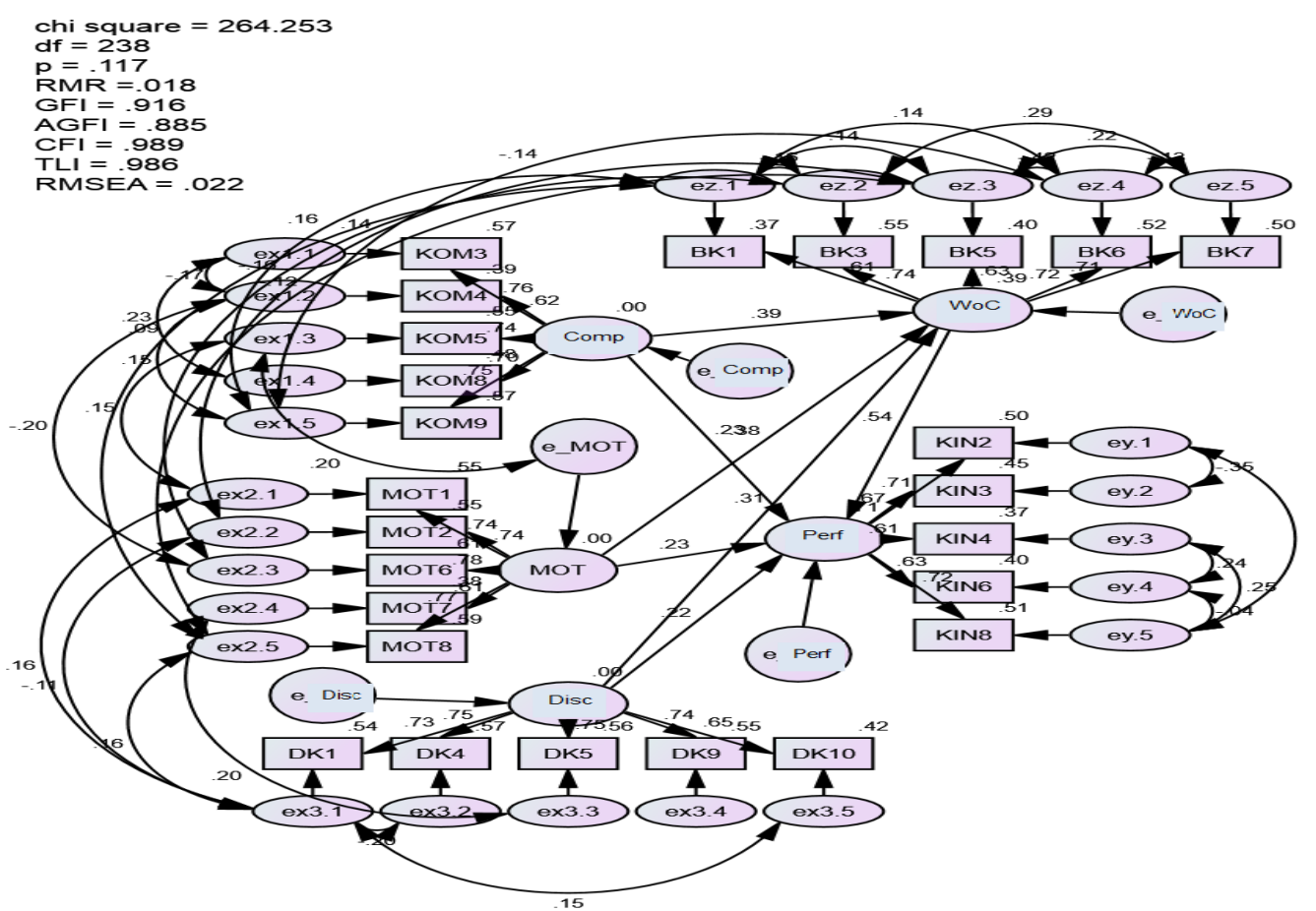

Figure 1 Measurement of the Relationship Model between Variables

The evaluation model shows that from the eight criteria of goodness of fit indices, the chisquared value has decreased with a fix value of 264,253 , although there are still criteria that do not match the value cut-off. More details the results of the phase 6 model test are evaluated 
based on the goodness of fit indices in Table 1 by presenting the criteria of the model and its critical values that have data compatibility.

Table 1. Evaluation of criteria for Goodness of Fit Indices Overall Model

\begin{tabular}{cccc}
\hline $\begin{array}{c}\text { Goodness of fit } \\
\text { (DF=38) }\end{array}$ & Cut-off Value & Results & Description \\
\hline Chi_Square & Small expected & 264.253 & Good \\
Probability & $\geq 0.05$ & 0.117 & Good \\
RMSEA & $\leq 0.08$ & 0.022 & Good \\
RMR & $\leq 0.05$ & 0.018 & Good \\
GFI & $\geq 0.90$ & 0.916 & Good \\
AGFI & $\geq 0.90$ & 0.885 & Marginal \\
TLI & $\geq 0.94$ & 0.989 & Good \\
CFI & $\geq 0.94$ & 0.986 & Good
\end{tabular}

The results of the model evaluation show that the eight criteria of goodness of fit indices have not fully met the criteria cut-off-value, namely the AGFI value. In this analysis has gone through six stages of modification of the model, then in step 6 as the final show there are seven criteria for goodness of fit indices have met the criteria or the appropriate cut-off-value, so that the model can be said to have been in accordance with the criteria of goodness of fit indices for analysis. Based on the empirical model proposed in this study, testing of the hypothesis proposed through testing the path coefficients of structural equation models can be tested. Table 2 is testing the hypothesis by looking at the $p$-value, if the $p$-value $=<0.05$ then the relationship between the variables is significant. Besides that, it also explains the direct effect, which means there is a direct positive effect between variables, indirect effects, which means there is positive an indirect effect between variables, and the total effect, namely the accumulation of direct and indirect effects. The test results are presented in the following table: 
Table 2. Direct, indirect and total effect

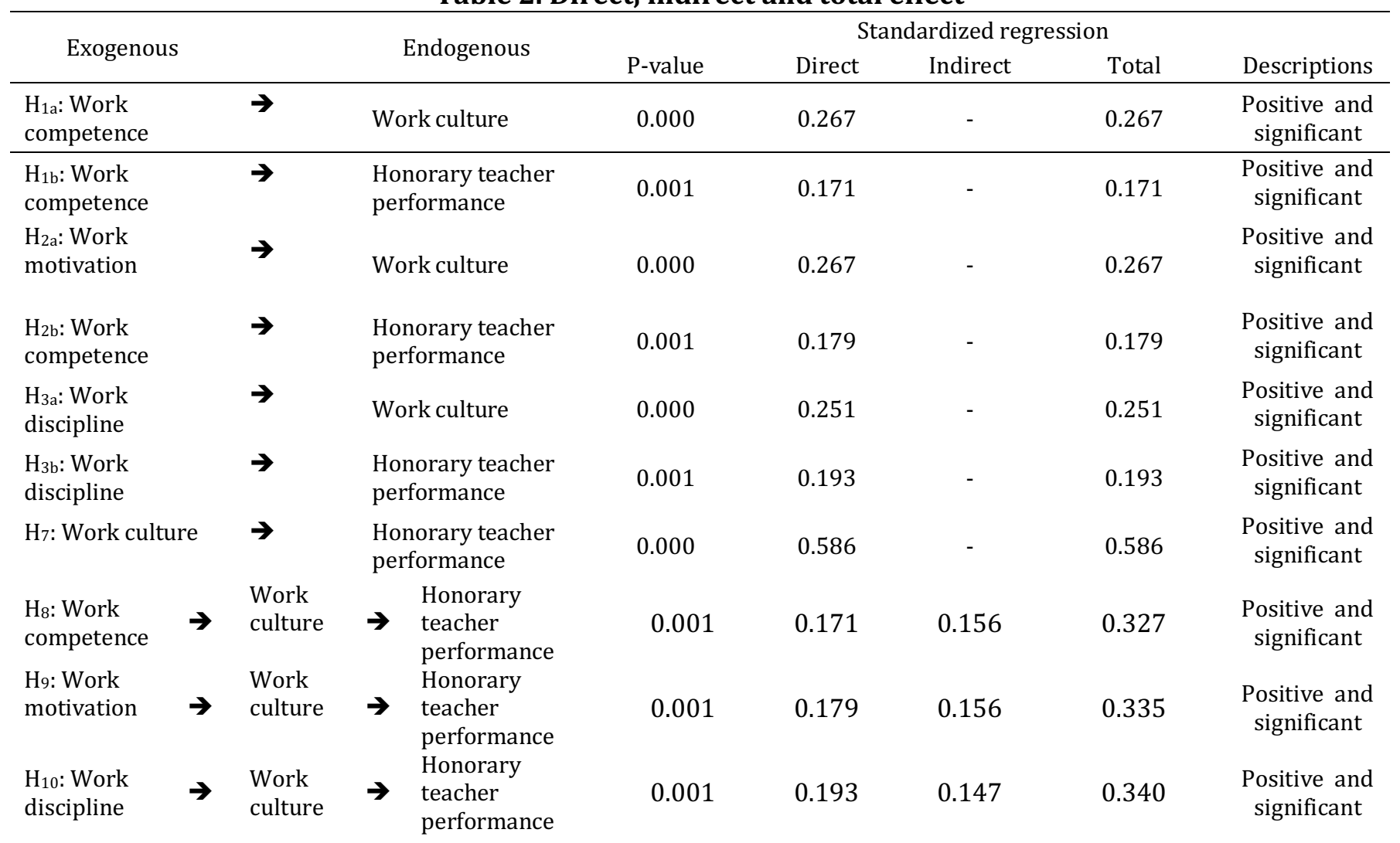

The seven direct path models and three indirect paths that are hypothesized, they all appear to have a positive and significant influence. Competence directly has a positive and significant effect on work culture with a p-value $=0.000<0.05$ and a coefficient of 0.267 , meaning that the competencies possessed by elementary school (SD) honorary teachers are good and correlate in showing a good work culture. Direct motivation has a positive and significant effect on work culture with a p-value $=0.000<0.05$ and a coefficient of 0.267 , meaning that elementary school (SD) honorary teachers have been motivated in teaching activities and correlated in showing a good work culture. Direct discipline has a positive and significant effect on work culture with a p-value $=0.000<0.05$ and a coefficient value of 0.251 , meaning that work discipline has been demonstrated by every elementary school honorary teacher and correlates according to the work culture that is applied and applies in school. Direct competence has a positive and significant effect on teacher performance with a p-value $=0.001<0.05$ and a coefficient of 0.171 , meaning that the competencies of elementary school (SD) honorary teachers contribute to the improvement of teacher performance.

Work motivation directly has a positive and significant effect on teacher performance with a pvalue $=0.001<0.05$ and a coefficient of 0.179 , meaning that elementary school (SD) honorary teachers are already motivated in teaching activities, so that they show good teacher performance. Work discipline directly has a positive and significant effect on teacher performance with a p-value $=0.001<0.05$ and a coefficient of 0.193 , meaning that work discipline has been demonstrated by every elementary school (SD) teacher correlating in supporting teacher performance improvement. The work culture directly has a positive and significant effect on teacher performance with a p-value $=0.000<0.05$ and a coefficient of 0.586, meaning that the creation of a work culture applied by teachers contributes to correlating the improvement of teacher performance. Competence through work culture has a positive and significant on teacher performance with the coefficient value of indirect effect is a 0.156 with a significance level $p$-value $=0.001<0.05$, proving that indirectly the competencies 
possessed are actualized according to work culture, thus contributing to improving the performance of honorary teachers.

Work motivation through work culture has a positive and significant on teacher performance with the coefficient value of indirect effect is a 0.156 with a significance level p-value $=0.001$ $<0.05$, proving that indirectly each teacher has been motivated in teaching in accordance with the work culture applies to schools, so that contributing to the improvement of honorary teacher performance and work discipline through work culture has a positive and significant on teacher performance with an indirect effect coefficient is a 0.147 with a significance level pvalue $=0.001<0.05$, proving that Indirect discipline has been shown by each teacher according to the applied work culture, thus contributing to the improvement of the honorary teachers performance.

\section{DISCUSSIONS}

Teacher competency directly has a positive and significant influence on the work culture of honorary teachers according to the abilities possessed by teachers in carrying out their duties as educators and instructors to have pedagogical competence, personality, socialization, professional and renaissance abilities that accumulate in them to develop work culture according to the level of adaptation and external and internal integration of honorary teachers. Work motivation directly has a positive and significant effect on honorary teacher work culture as demands for needs, achievements, recognition and expectations for physiological fulfillment, security, social interaction, appreciation and self-actualization that encourages and encourages to develop work culture according to the form of adaptation and integration external and internal owned by honorary teachers.

Work discipline directly has a positive and significant effect on honorary teacher work culture which makes each teacher have an attitude of behavior, discipline to develop learning, adherence to rules, adherence to policy and loyalty to leaders in carrying out teaching and learning tasks in accordance with the applicable work culture in school externally and internally encourages teachers to be able to adapt and integrate. Competence directly has a positive and significant effect on honorary teacher performance by demonstrating the teacher's ability to develop and accumulate potential possessed pedagogically, personality, socialization, professionals and renaissance to work competently in improving their performance in accordance with quality, quantity, efficiency and effectiveness in teaching in elementary school. Work motivation directly has a positive and significant effect on honorary teacher performance, which is reflected in the enthusiasm, encouragement and stimulation that grows from within and outside of itself to always meet the demands of physiological needs in teaching, materializing a sense of security in teaching, social interaction with all school members, requires appreciation for teaching achievements, and wants self-actualization in accordance with praise or recognition given for the achievement of performance produced in realizing the quality of teaching received in quantity by many students by obtaining efficient and effective lessons.

Work discipline directly has a positive and significant effect on the performance of honorary teachers in accordance with the assessment that requires every teacher to have discipline in behaving in an orderly manner, develop discipline of learning regularly, have adherence to the provisions of the school, have high loyalty to the leadership, this discipline leads honorary teachers are able to improve their performance in quality, quantity, efficient and effective. The work culture directly has a positive and significant effect on the performance of honorary teachers in adopting and integrating externally and internally all educational and teaching activities in schools to improve teacher performance in quality in teaching, quantity for 
students taught, efficient in teaching timeliness and effective in learning material provided. Competence through work culture indirectly has a positive and significant effect on the honorary teacher's performance.

Teacher's competency in the form of pedagogic, personality, socialization, professionalism and renaissance has been actualized through work culture in adaptation and integration both externally and internally in improving the performance of honorary teachers. Work motivation through work culture indirectly has a positive and significant effect on the performance of honorary teachers. Motivation in the form of fulfilling physiological needs, security, interaction, appreciation and self-actualization by the teacher has been actualized through work culture in adaptation and integration both external and internal in improving the performance of honorary teachers and work discipline through a work culture indirectly has a positive and significant effect on performance honorary teacher. Work discipline in the form of behavior, learning, obedience, obedience and loyalty applied by the teacher has been actualized through a work culture in adaptation and integration both externally and internally in improving the honorary teacher's performance.

\section{References}

Asmani, JMM (2009). Seven Fun and Professional Teacher Competencies. Jogjakarta: Power Books

Dessler, G. (2003). Human resource management. (9th ed.). Upper Saddle River, NJ: Prentice-Hall. ।

Gagne, R. (2002). The Learning Media to Smart People. Published by West Publishing Company, New York.

Handoko, T. Hani. (2007). Management. Yogyakarta: BPFE Yogyakarta, 18 Ed.

Hasbullah. (2006). Education Autonomy, Jakarta: PT. Raja Grafindo

Kreitner, Robert. \& Angelo, Kinichi. (2009). Organizational Behavior, Third Edition USA D Irwin Inc.

Syah, Muhibbin. (2003). Learning Psychology. PT. Raja Grafindo Persada: Jakarta

Tanner, Jacob. (2001). The Flexible in Education Management. London School of Education, London.

Terry, GR (2005). Human Resource Management. Published by McGraw-Hill, Ohio 